\title{
Applying DACUM Approach and WIDS Program Application to Curriculum Development of Vocational High School in Indonesia
}

\author{
Gunadi Tjahjono \\ Department of Vocational and Technology Education Nusa Cendana University \\ Jl. Adisucipto Penfui- Kupang 85000 INDONESIA \\ gunaditjahjono@gmail.com
}

\begin{abstract}
The purpose of this research is producing basic competence and validating task analysis of basic competence on productive subject, electrical engineering competence. Development method of basic competence for productive subject in Vocational High School using developing of curriculum (DACUM) approach, especially for task analyzing. Validation technique applying with world instructional design system (WIDS) program application in trial version 75125 . The object of the research is competence skill electrical engineering in Transmission Service Unit PT PLN Special Regional Yogyakarta, subject of research is the employees, operators and technician of transmission and Central transmission Service Unit. The result of research reveals description of basic competence in Sub-division of maintenance and operational towards electrical transmission engineering: there are 12 groups of job and 32 work obligation component, and 160 tasks.
\end{abstract}

Index Terms - DACUM, basic competence, electrical transmission engineering.

\section{Introduction}

The problem about the implementation of standard content in Vocational High School is explained by Reference [5]: there is not permanent standard content (Basic standard and basic competence) for productive subject (skill program) and there is not standard content (competence standard and basic competence) which support skill program. The optional ways that government does are (1) arrange competence standard and basic competence for productive subject in Vocational High School by adapting relevant aspect of curriculum 2004 ; (2) sanctioning from the result of competence standard and basic competence among skill program grouping; and (3) formulating content standard (competence standard and basic competence) skill basic material done by a group of skill program teacher or Profession standard national institution or directorate of Vocational High School Counseling.

Reference [3] was commit: (1) Vocational Competence Standard is a Education National Standard which fulfill subject component standard as ruled in the regulation of National Education Minister No. 22, 2006 about content standard for basic and middle education unit; (2) Vocational Competence standard as explained in verse (1) state that Basic Vocational Competence as explained in Vocational High School Curriculum as ruled in The regulation of National Education Minister No. 22, 2006 about Content Standard for Basic Education and Middle Unit. There are 17 competence standard and 76 basic competences in Electrical Distribution Engineering, while in Electrical Transmission Engineering Skill competence there are 19 competence standard and 82 basic standards (the regulation of National Education Minister No. 2, 2009 enclosed). Competence standard and basic competence available is applied for Vocational Competence subject in which called as productive subject group.

Reference [2] was commit the arrangement of curriculum in primary level education unit and middle refers to content standard and graduate competence standard and also based on the guidance arranged by Institution of Education National Standard. National curriculum which is arranged and implemented by each education unit is known as education level curriculum means content standard and graduate competence standard is implemented in Curriculum Education Unit (CEU) form, basically CEU is curriculum based on competence which is developed by education unit based on content standard, standard of graduate competence and basic competence.

CEU Vocational High School developed based on principles [1] follow: (1) concern to potential, development, needs, and the needs of students and environment as the center; (2) various and united (3) responsive towards science, technology and art development: (4) relevant with life needs: (5) comprehensive and good synergy (6) long life education. Learning materials must reveal a piece of competence standard and articulation for competence standard level.

Based on the explanation above, the problem of this research can be can be identified as follow: (1) whether to carry out a review of the basic competence for productive subject group?; (2) should basic competence in Vocational High School be centralized in Industrial World development?; (3) how various are the components which form basic competence of Vocational High School?; (4) what kind of sub component used as signal indicator for basic competence achievement, signed by behavior change which can be measured and consist of attitude, knowledge and skill?; (5) do Vocational High School need to be more perfect as work world accusing, National Competence Standard, and need of ability preparation for adapting with science-technology development?; (6) should Vocational High School Curriculum or competence of standard from Vocational High School be planned as curriculum based on competence in order to fulfill the need of work field?; (7) Should Vocational High School prepare its graduate with standard of graduate's competence which is suitable with employee demands professional in electrical Engineering?; (8) is it needed special concentration related with professional worker for Vocational High School in order to be suitable worker who work in PT PLN (PERSERO)) Indonesia? 
Reference [4] explains that there are 4 approach strategies in identifying content of curriculum for technology and vocational education, there are: (1) philosophy approach; (2) introspection approach; (3) DACUM approach; and (4) task analysis approach. Finch explains at the same page, curriculum focus on position or job traditionally tends to $\mathrm{b}$ closer to worker activity which is centralizing on specific task and activity. Competition and change must be suitable with demand of electrical company in work world. In this case, approach that is closer to world work need are task analysis approach and DACUM.

\section{Method}

DACUM analysis is job analysis. Collection data technique with an expert Panel of DACUM applied four steps as follow: (1) expert worker panel is started by developing the title of work field and definition;(2) place a group of job on organization structure; (3) identify approximately 5-10 main task into work obligation; (4) work task is group or related into each identified obligation: (5) job profile validation done by inviting manager as input supporter. This research uses 5 instruments as a guide in taking the data. The instruments are: (1) participant criteria or expert; (2) duty statement criteria; (3) task statement development guide; (4) task-statement criteria; and (5) work activity criteria [7], [8]

DACUM analysis is applied for implementing job analysis. For getting data deeper, job analysis interview is done, especially sub component of job activity, knowledge, tools and measurement device which is used trough meant communication process with some supervisors and manager as employee. Job analysis validity applied reference construct validation. There several stages, (1) describing job activity (what, why, how the work is conducted); (2) identifying main function of job position; (3) describing competences (knowledge, skill, ability and attitude) needed for conducting the job activity and this competence formed in target elements which can be observed and measured.; (4) describing the readiness factors which s related to work demand context as an environment, mental, and physically demands, availability and willingness; (5) delivering the importance of job activity components and competence; (6) information resource notes, such as date of analysis [6].

Task analysis validation technique uses 3 kinds of strategies, as follow: (1) validation strategy-parameter reference uses mathematical correlation between work performance in the examination and work performance in the real job; (2) validation strategy reference-content is a strategy which is built for work performance during the examination as relative respondent at the real work place; (3) validation strategy construct reference, this strategy often uses statistics data and it is applied on personality criteria measurement. Construct is not used to observe behavior but it tends to characteristics, such as intelligence and motivation which refer to behavior observation [6]. Validating job analysis uses DACUM refers to five components, there are: participant criteria or expert, duty statement criteria, task-statement development, taskstatement criteria (task), job activity criteria [7], [8].

Informant as Information resource in this research is an expert at her/ his work field with these requirements [7], [8]; (1) having high technical competence in that field or minimal as a supervisor; (2) permanent worker at a company; (3) representation at the same job in order to analyze the job; (4) good communicator; (5) capable at working group; (6) willing to involve; and (7) not accurate. Duty statement expected as follow: (1) description with wide work field; (2) part of duty group consist of 6-20 duties; (3) consist of one activity; (4) independent, without depend on others. Duty statement development guide, consist of three components, statement, there are: (1) verb, it must be singular-first person and active sentence; (2) object, it is an activity done by worker; and (3) qualifiers, words or phrase used to give limitation and explain a statement of task. Task statement criteria must be: (1) describe a task in work performance in brief; (2) having one work action and another object which receive action; (3) as usual in consist of one of more than one qualifier or give task statement clearly and relevant; (4) independent from obligation or another task; (5) avoiding to mention knowledge needed; (6) clearly formulated; (7) avoid mentioning attitude needed; (8) avoid mentioning tools and equipment which only support task activity. Activity criteria (task duty) must reflect several things as follows ; (1) representation the smallest job as activity which produce outcome; (2) the result is a product, service or decision; (3) work unit presentation; (4) measureable and observable; (5) capable to conduct In a short period; (6) free from another task; (7) consist of 2 or more than work step.

\section{Result and Research Analysis}

a. Description of basic competence components towards electrical transmission engineering competence.

1) Occupational Cluster: Transmission and substation network $150 \mathrm{KV}$ has 4 group of tools, they are ; (1) main tools consist of; power transformer bay, line bay, couple bay, high voltage air line (HVAL) and High Voltage Cable Line (HVCL). Power transformer bay, line bay and couple bay consist of; circuit breaker (CB), disconnection switch (DS), current transformer (CT), potential transformer (PT), Lightning Arrester (LA). HVAL and HVCL consist of; grounding, conductor, isolator and cable. (2) protection tools and panel consist of transformer protection and conductor protection. transformer protection consist of relay over current relay (OCR) , Ground fault relay (GFR), relay Buchloz, sudden pressure, differential, distance, Jansen on load tap changer (OLTC), Restricted Earth Fault (REF) relay and temperature sensor; (3) resource tools DC consist of charger, battery 110 Volt and Battery 48 Volt ; (4) Supervisory Control and Data Acquisition (SCADA) tools and telecommunication consist of communication radio, power line carrier (PLC), remote terminal unit (RTU) and private automatic box exchange (PABX).

Results of this research are 12 occupational clusters that is needed to arrange basic competence on electrical transmission engineering skill competence. Occupational cluster consist of : (1) maintenance of power transformer ; (2) conductor maintenance; (3) maintenance couple bay; (4) maintenance of HVAL; (5) maintenance of measurement transformer protection; (6) maintenance of conductor protection; (7) battery maintenance; (8) charger maintenance; (9) maintenance of communication radio; (10) PLC maintenance; (11) RTU maintenance; (12) PABX maintenance. 
2) Duty Components: Duty has 32 duties needed to arrange electrical transmission engineering skill competence. Description of occupation cluster and tasks can be seen on the table -1 .

Table-1. Components Work Group and Employment Obligations Competencies Expertise in Power Transmission Engineering

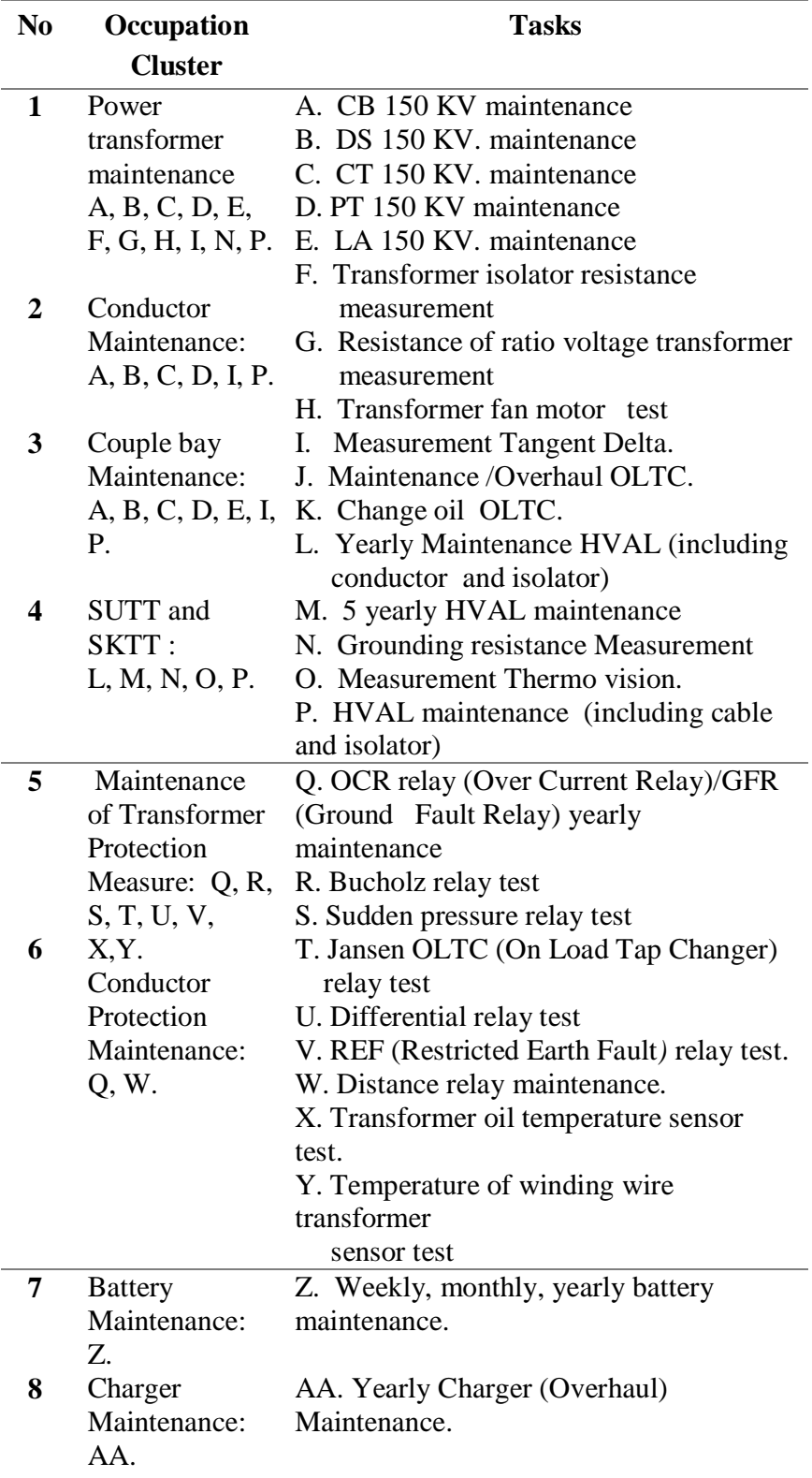

\footnotetext{
9 Communication BB. Communication radio maintenance. radio $\quad \mathrm{CC}$. Tools distance protection PLC maintenan-ce: (power line carrier) maintenance.

10. BB. Maintenance:

11. PLC: $\mathrm{CC}, \mathrm{FF}$ Maintenance RTU: DD.

12. $\mathrm{PABX}$ Maintenance PABX: EE.
}

3) Task Component: Five main tasks are needed to arrange electrical transmission skill basic competence are; job acting planning, preparing job implementing, job implementing, making implementing report, evaluating job implementation result. Those five jobs applied on each duty, because on the transmission field and substation 150 $\mathrm{KV}$ has 32 duty so all tasks become 160 duty including electrical transmission engineering skill competence basic competence former. The description of 3 from 32 duties is explained in Table- 2 .

Table-2. Job Task Component Forming Basic Competence Technical Expertise in Competency Power Transmission

\begin{tabular}{|c|c|c|c|c|c|}
\hline No & Plan & Preparatio & ntation & Report & Evaluation \\
\hline 1 & $\begin{array}{l}\text { Plan the } \\
\text { maintenanc } \\
\mathrm{e} \\
\text { implement } \\
\text { ation for } \\
\mathrm{CB} \\
150 \mathrm{KV}\end{array}$ & $\begin{array}{l}\text { Prepare the } \\
\text { maintenan } \\
\text { ce } \\
\text { implement } \\
\text { ation for } \\
\text { CB } 150 \\
\text { KV }\end{array}$ & $\begin{array}{l}\text { Implement } \\
\text { the } \\
\text { maintenanc } \\
\text { e for CB } \\
150 \mathrm{KV}\end{array}$ & $\begin{array}{l}\text { Make } \\
\text { report } \\
\text { about the } \\
\text { maintenan } \\
\text { ce } \\
\text { implement } \\
\text { ation for } \\
\text { CB } 150 \\
\text { KV }\end{array}$ & $\begin{array}{l}\text { Evaluate } \\
\text { the } \\
\text { maintenanc } \\
\mathrm{e} \\
\text { implement } \\
\text { ation CB } \\
150 \mathrm{KV}\end{array}$ \\
\hline 2 & $\begin{array}{l}\text { Plan the } \\
\text { maintenanc } \\
\text { e } \\
\text { implement } \\
\text { ation for } \\
\text { DS } 150 \\
\text { KV }\end{array}$ & $\begin{array}{l}\text { Prepare the } \\
\text { maintenan } \\
\text { ce } \\
\text { implement } \\
\text { ation DS } \\
150 \mathrm{KV}\end{array}$ & $\begin{array}{l}\text { Implement } \\
\text { the } \\
\text { maintenanc } \\
\text { e for } \\
\text { DS } 150 \mathrm{KV}\end{array}$ & $\begin{array}{l}\text { Make } \\
\text { report } \\
\text { about the } \\
\text { maintenan } \\
\text { ce } \\
\text { implement } \\
\text { ation DS } \\
150 \mathrm{KV}\end{array}$ & $\begin{array}{l}\text { Evaluate } \\
\text { the } \\
\text { maintenanc } \\
\mathrm{e} \\
\text { implement } \\
\text { ation DS } \\
150 \mathrm{KV}\end{array}$ \\
\hline 3 & $\begin{array}{l}\text { Plan the } \\
\text { maintenanc } \\
\text { e } \\
\text { implement } \\
\text { ation for } \\
\mathrm{CT} \\
\text { (Current } \\
\text { Transform } \\
\text { er) } 150 \mathrm{KV}\end{array}$ & $\begin{array}{l}\text { Prepare the } \\
\text { maintenan } \\
\text { ce } \\
\text { implement } \\
\text { ation CT } \\
\text { (Current } \\
\text { Transform } \\
\text { er) } 150 \mathrm{KV}\end{array}$ & $\begin{array}{l}\text { Implement } \\
\text { the } \\
\text { maintenanc } \\
\text { e for CT } \\
\text { (Current } \\
\text { Transforme } \\
\text { r) } 150 \mathrm{KV}\end{array}$ & $\begin{array}{l}\text { Make } \\
\text { report } \\
\text { about the } \\
\text { maintenan } \\
\text { ce } \\
\text { implement } \\
\text { ation CT } \\
150 \mathrm{KV}\end{array}$ & $\begin{array}{l}\text { Evaluate } \\
\text { the } \\
\text { maintenanc } \\
\text { e } \\
\text { implement } \\
\text { tion CT } \\
\text { (Current } \\
\text { Transforme } \\
\text { r) } 150 \mathrm{KV}\end{array}$ \\
\hline
\end{tabular}

b. Basic Component Data Analysis Towards Electrical Transmission Engineering Competence

Data analysis refers to content analysis which is suitable with research question, there are: (1) occupational cluster component; (2) duty component; (3) task component. Character from this analysis is a description from phenomenology research method and result from thematic data analysis result produce an interpretation from phenomenology research method. The research conducted based on phenomenology research method panel expert suggested according to the principle or basic assumption used in DACUM include these three terms: (1) only experts who are able to describe and definite their job accurately;(2) the effective ways to definite duty and task conducted by experts; (3) in order to the task correctly conducted, it needs knowledge, skill, attitude, behavior and special tools. 
Individual who is pay role as participant or the informant should be fulfill the criteria as an expert in the work field as good requirements as follow: (1) having high technical competence or minimal as a supervisor; (2) permanent worker at the company; (3) representation from kinds of job in order to be able to analyze the job; (3) good communicator; (4) capable at working team; (5) willing to involve fully and (\&) free from bias.

Panel expert who participate are 8 people for substation supervisor (Switch yard), they are: transmission and substation supervisor in Bantul, transmission and substation supervisor in Semanu Wonosari, transmission and substation supervisor in Wates, transmission and substation supervisor in Medari, transmission and substation supervisor Godean, transmission and substation supervisor in Kentungan, transmission and substation supervisor in Wirobrajan, transmission and substation supervisor in Gejayan. Panel expert realization organized and facilitated by manager, operation and maintenance manager assistant, planning and evaluation of manager assistant UPT PT PLN, Yogyakarta. Panel expert implementation for job analysis using DACUM applies data and thematic analysis. There are seven stages for implementing thematic data analysis, they are: (1) listening to the participant narration for understanding meaningful participant narration; (2) focus on phrase and sentence related to the topic of the research and get accurate statement; (3) meaning formulation; (4) cluster of themes;(5) exhaustive description; (6) formulate all cluster themes become fundamental structure; (7) validating among participant (member check). Validating conducted based on the requirement of data collection technique towards research method which invites manager, operational manager assistant, planning assistant manager and evaluation, a person who is experienced in the plan field and evaluation in PT PLN, Unit transmission, Yogyakarta.

1) Occupational Cluster: Occupational cluster produces 12 statements of occupational cluster formed based on 4 main tools on transmission net and relay station 150 $\mathrm{KV}$, there are: (1) main tools consist of power transformer bay, line bay, couple bay, SUTT and SKTT; (2) protection tools and panel, consist of, transformer protection tools, conductor protection tools; (3) tools of DC resource consist of, communication, PLC, RTU and PABX.

Based on DACUM requirements, the stages of job analysis as follow : (1) panel expert started by development the title the work field and the definition; (2) replace the kinds of job in a organization structure; (3) identify about 510 main tasks; (4) task is classified with identified duty; (5) job profile validation, conducted and invite managers and input strengthen.

Transmission and substation supervisor panel produce name of work union from work field conducted based on task as a supervisor and the responsibility towards transmission operational and main voltage regulator 150 $\mathrm{KV}$. The task and responsibility of supervisor are managing information for the real time work, facilities and physical safety, supervise operational and troubleshooting to get the readiness of transmission installation and main voltage regulator $150 \mathrm{KV}$. Responsibilities of supervisor are: (1) arrange activity plan in substation (2) managing installation asset, substation and transmission facility; (3) doing inspection towards substation tools condition and transmission to preserve uncontrollable problems; (4) supervise the operation of substation installation tools as standard operational procedure (SOP); (5) supervise application of occupational health and safety in job implementation; (6) coordinate the arrangement of substation installation; (7) coordinate environment safety supervision; (8) supervise KWH download transaction; (9) conducting operational administration for operational and maintenance for substation; (10) associate and develop human resource competence as job competence need.

Placement of occupational cluster set after the tools used in the main voltage regulator and transmission, produce 12 work field or occupational cluster in which each will be connected with identified responsibility. Identified responsibility refers to the following table-1, consist of; (1) maintenance of power voltage regulator including duty A,B,C,D,E,F, G,H,I,N,P.; (2) conductor maintenance including duty A,B,C,D,I,P; (3) maintenance of couple bay including A,B,C,D,E,I,P; (4) maintenance HVAL and HVCL including duty L, M,N,O,P; (5) maintenance of measurement transformer including Q,R,S,T,U,V,X,Y; (6) maintenance of conductor protection $\mathrm{Q}, \mathrm{W}$; (7) selecting battery including duty $\mathrm{Z}$;(8) charger selecting including duty AA (9) Communication radio selection including duty BB; (10) PLC maintenance including duty CC and FF; (11) maintenance RTU including duty DD; (12) maintenance PABX including duty EE. Twelve occupational clusters in transmission field and main voltage regulator $150 \mathrm{KV}$ is a reference for describing component and sub competence transmission field and main voltage regulator $150 \mathrm{KV}$. The intended components are duty and task. Sub component are job activity, knowledge, tools, work equipment and attitude.

Validation conducted in occupational cluster is only rational judgment by UPT manager, UPT operational and maintenance assistant manager, planning and evaluation assistance manager, and a person who is experienced in plan and evaluation P.T PLN Yogyakarta transmission service unit.

2) Employment Liability Component (Duty): Duty produced based on criteria guide of duty statement in DACUM; (1) description about wide work field; (2) it's a part of occupational cluster consist of about 6-20 duty; (3) consist of one activity, one object and qualifier or clarify task; (4) independent.

This research produces 32 duties in transmission field and main voltage regulator $150 \mathrm{KV}$, code A-EE. Duty component is a part forms certain occupational cluster. The first occupational cluster consist of 11 duties, they are; A,B,C,D,E,F,G,H,I,N,P. second occupational cluster consist of six duties, they are A,B,C,D,I,P, the third occupational cluster are A,B,C,D,E,I,P. the fourth are L,M,N,O,P. the fifth are $\mathrm{Q}, \mathrm{R}, \mathrm{S}, \mathrm{T}, \mathrm{U}, \mathrm{V}, \mathrm{W}, \mathrm{X}, \mathrm{Y}$. the sixth are $\mathrm{Q}, \mathrm{W}$. the seventh to twelve, each has 1 duty, they are ; Z,AA,BB,CC,FF,DD and EE.

Each duty has verb and object but it doesn't always have qualifier or clarify task. For example, test of Buchloz Relay without qualifier or clarify task statement. In other case, those who use qualifier or clarify task statement is yearly maintenance over current Relay. Validation conducted on duty is only validating content. This validation is rational judgment by UPT manager, operational and maintenance UPT manager assistant, planning and evaluation manager 
assistant, and a person who is experienced in planning and evaluating P.T PLN Yogyakarta Transmission service unit.

3) Task component: Task component that has been produced formed based on task and task criteria development guide. Three components of task development guide are; (1) verb, it must be the singular and first person and active sentence; (2) object, it is an activity conducted by worker; (3) qualifier, it is phrase or sentence used to give limitation and clarify task statement. Task criteria must be statement; (1) describe a task in brief in form of work performance; (2) having one work action and one object who receive an action; (3) it consists of one or more qualifier or qualifier or clarify task relevantly as usual (4) independent from another task and duty (5) avoid mentioning the knowledge needed (6) clearly formulated (7) avoid mentioning attitude needed (8) avoid mentioning equipment and tools that only support task activity.

There are 5 main jobs in transmission and substation 150 $\mathrm{KV}$ they are: planning, preparation, implementing, making report, evaluating a job is implementation. The result of the research are 160 component of task coded A.1, A.2, A.3, A.4, A.5 to FF.1, FF.2, FF.3, FF.4 and FF.5. Construction explanation of task sentence, for example A.1 maintenance implementation planning circuit breaker $150 \mathrm{KV}$, it can be explained that title construction of task component including; task in a form of work performance by planning the implementation, it consists of one work action, maintenance and one action receiver object circuit breaker, it consist of one or more qualifier, classification $150 \mathrm{KV}$. Description of competence frequency as electrical transmission engineering skill competence can be seen on the table-3

Table-3. Competence Frequency as Electrical Transmission Engineering Skill Competence

\begin{tabular}{|c|c|c|c|c|c|c|c|c|}
\hline \multirow[t]{2}{*}{ No } & \multirow[t]{2}{*}{ Task description } & \multicolumn{7}{|c|}{ Key Competence Frequency } \\
\hline & & 01 & 02 & 03 & 04 & 05 & 06 & 07 \\
\hline 1 & $\begin{array}{l}\text { Plan disconnection switch } \\
\text { maintenance implementation } \\
\text { (PMT) } 150 \mathrm{KV}\end{array}$ & 1 & 2 & 60 & 6 & - & - & 1 \\
\hline 2 & $\begin{array}{l}\text { Prepare disconnection switch } \\
\text { maintenance implementation } \\
\text { (PMT) } 150 \mathrm{KV}\end{array}$ & - & 58 & 2 & 10 & - & - & - \\
\hline 3 & $\begin{array}{l}\text { Implement disconnection switch } \\
\text { maintenance (PMT) } 150 \mathrm{KV}\end{array}$ & 1 & 1 & - & 66 & - & - & 2 \\
\hline 4 & $\begin{array}{l}\text { make disconnection switch } \\
\text { maintenance implementation report } \\
\text { (PMT) } 150 \mathrm{KV}\end{array}$ & 56 & 3 & - & 8 & 3 & - & - \\
\hline 5 & $\begin{array}{l}\text { Evaluate disconnection switch } \\
\text { mainte- nance implementation result } \\
\text { (PMT) } 150 \mathrm{KV}\end{array}$ & 5 & 1 & - & 9 & 2 & 53 & - \\
\hline
\end{tabular}

Note :

01. Able to collect, organize and analyze information

02. Able to communicate ideas and information

03. Able to plan and organize activity

04. Able to work in group

05. Able to use ideas and mathematics technique

06. Able to Solve the problem

07. Able to operate technology
Result of construct validity and reliability continued by making DACUM survey for key competence and work level in each job. Result of key competence frequency for transmission and substation $150 \mathrm{KV}$, explained in table-3, generally, planning implementation has the most frequency in key competence to plan and organize activity. Task prepares maintenance implementation has the most key competence is able to communicate ideas and information. Task of maintenance implementation has the most frequency in the key competence is able to work in group. Task of making report of implementation maintenance has the most frequency of key competence is able to collect, organize and analyze information. Task evaluate the result of maintenance implementation has the most key competence which is able to solve the problem.

Work level frequency for transmission and substation $150 \mathrm{KV}$ explained in Table-4. Generally, task of maintenance implementation are preparing the implementation, implement the maintenance and evaluate result of maintenance implementation having the most frequency in second work level must be able to manage process and criteria determination for process evaluation. Task makes report of maintenance implementation having the most frequency in the first level, it must conduct determined process and it is able to appraise a quality based on determined criteria.

Table-4. Skill Competency of Working Level Frequency Power Transmission Engineering

\begin{tabular}{clrrr}
\hline \multirow{2}{*}{ No } & \multicolumn{1}{c}{ Task description } & \multicolumn{3}{c}{ Work level } \\
\cline { 2 - 5 } & 01 & 02 & 03 \\
\hline \multirow{2}{*}{1} & $\begin{array}{l}\text { Plan disconnection switch maintenance } \\
\text { implementation CB 150 KV }\end{array}$ & 86 & 6 \\
2 & $\begin{array}{l}\text { Prepare disconnection switch } \\
\text { maintenance implementation CB 150 KV }\end{array}$ & 11 & 59 & - \\
3 & $\begin{array}{l}\text { Implement disconnection switch } \\
\text { maintenance CB 150 KV }\end{array}$ & 15 & 55 & - \\
4 & $\begin{array}{l}\text { make disconnection switch maintenance } \\
\text { implementation report CB 150 KV }\end{array}$ & 58 & 10 & 2 \\
5 & $\begin{array}{l}\text { Evaluate disconnection switch maintenance } \\
\text { implementation result CB 150 KV }\end{array}$ & 56 & 9 \\
\hline
\end{tabular}

Note :

01. Able to implement determined process; and appraise a quality based on determined criteria.

02. Able to manage process and decide criteria to analyze process

03. Able to decide principle and process; evaluate and change process; and decide criteria to evaluate process

\section{Conclusion}

Conclusion from this research classified into 2 parts, they are based on description result and interpretation of phenomenology result:

a. There are twelve occupational clusters and 32 duty components as a former of basic competence toward sub maintenance and operational in electrical transmission engineering skill competence.

b. There are 160 tasks as former of basic competence toward sub maintenance and operational in electrical transmission engineering skill competence. 


\section{References}

[1] BSNP (Badan Standar Nasional Pendidikan). Landasan Pengembangan CEU, 2007.

[2] Depdiknas. Undang-Undang NO. 20 Tahun 2003, tentang Sistem Pendidikan Nasional, 2003.

[3] Depdiknas. Peraturan Menteri Pendidikan Nasional Nomor 28 tahun 2009, tentang Standar Kopetensi Kejuruan Sekolah Menengah Kejuruan (SMK)/Madasah Aliyah Kejuruan (MAK), 2009.

[4] Flinch, C. R. \& Crunkilton, J. R. Curriculum development in vocational and technical education. Boston: Allyn and Bacon Inc., 1999.

[5] Harianti, D. Naskah Akademik Kajian Kebijakan Kurikulum SMK, Jakarta: Puskur Badan Litbang Depdiknas, 2007.

[6] Human Resource Personnel (2005). Job analysis guide. www.siop.org/ Principles/principles.pdf.

[7] Norton, R. E. DACUM handbook. Ohio: Center of Education and Training for Employment College of Education, 1997.

[8] Norton, R. E. \& Moser, J. R. DACUM handbook. Ohio: Center of Education and Training for Employment College of Education, 2008. 